\title{
Does intravenous dipyridamole administration cause acute renal impairment?
}

\author{
Muhsin Kalyoncuoglu' ${ }^{*}$, Murat Baskurt ${ }^{2}$ and Kamil Gulsen ${ }^{3}$ \\ ${ }^{1}$ Department of Cardiology, Haseki Training and Research Hospital, Turkey \\ ${ }^{2}$ Department of Cardiology, Istanbul Bilim University, Turkey \\ ${ }^{3}$ Department of Cardiology, Bagcilar Training and Research Hospital, Turkey
}

\begin{abstract}
Purpose: Dipyridamole increases extracellular adenosine concentrations, and may result a significant decrease on GFR. The aim of the study was detect whether any deterioration occurs in renal function in patients who were undergoing dipyridamole myocardial perfusion scintigraphy.

Material and method: 94 patients (64 women, 30 men, mean age; $69 \pm 10$ ) undergoing dipyridamole myocardial perfusion scintigraphy enrolled to our study. Blood samples were taken from all patients for serum creatinine and cystatin $\mathrm{C}$ before and at 4 th and 48 hours after the test. The patients were divided into two groups as GFR value higher (group A) and equal or lower (group B) than $60 \mathrm{~mL} / \mathrm{dk} / 1.73 \mathrm{~m}^{2}$ according to GFR calculation modalities. The development and incidence of nephropathy $(25 \%$ increase in serum creatinine or cystatin $\mathrm{C}$ level from the baseline value at 4 th and 48 th hours after administration of dipyridamole) was determined betweeen the two groups.

Result: Group B were significantly elder and more hypertensive than group A. Serum creatinine levels did not exhibit any difference between the groups at 4th and 48th hours in all calculation modalities. Besides that, only 4th hours cystatin C level showed significantly increasing in in patients with MDRD-GFR < 60 mL/ $\mathrm{dk} / 1.73 \mathrm{~m}^{2}$ whereas 48 th hours cystatin $\mathrm{C}$ levels did not. Any change in cystatin $\mathrm{C}$ levels also were not observed between the groups in other calculation modalities.

Conclusion: Dipyridamole myocardial perfusion scintigraphy can be used safely in patients with GFR $\leq 60 \mathrm{~mL} / \mathrm{dk} / 1.73 \mathrm{~m}^{2}$ except end stage renal disease.
\end{abstract}

\section{Introduction}

Dipyridamole myocardial perfusion scintigraphy (MPS) is extensively used as an pharmacological stress test for the diagnosis of coronary artery disease and risk assessment in patients who are unable to achieve an acceptable level of exercise [1]. Dipyridamole blocks the reabsorption and metabolism of adenosine via reducing the uptake of adenosine by cells and thereby increases extracellular adenosine concentrations [2]. The vascular effect of dipyridamole has been attributed to increases level of endogenous adenosine $[3,4]$. Although increased extracellular adenosine causes vasodilatation in most vascular beds such as coronary and cerebrovascular system; it predominantly induces vasoconstriction in renal vascular bed and lowers glomerular filtration rate (GFR) which has been demonstrated previously [5-8]. Additionally, there is evidence that adenosine has an important role in pathophysiological process of acute reduction in renal function following contrast media (CM) exposure by inducing sustained renal vasoconstriction and a reduction in GFR [5,9-10].

Although being the most commonly used marker to estimate the impairment of renal function and GFR; the serum creatinine (SCr) has a low sensitivity for the detection of early renal impairment especially in patients with small to moderate decreases in GFR [11-14]. Cystatin-C (Cys-C) is an endogenous cysteine protease inhibitor and produced by nucleated cells at a constant rate [14]. It is freely filtered and catabolized in proximal tubulus without being secreted and reabsorbed. So, serum concentration of Cys-C is determined by glomerular filtration and used as a marker for GFR. Contrast to SCr, serum Cys-C concentration is less dependent on factors such as age, sex, and muscle mass [11,15-18].
It has been also reported that serum Cys- $\mathrm{C}$ is more sensitive indicator of even mildly reductions in GFR and may detect the acute changes in GFR earlier than SCr in some clinical conditions such as acute renal failure, contrast induced nephropathy (CIN) , diabetic nephropathy, hypertensive nephropathy $[11,16,17]$.

It has been reported that the vascular effect of dipyridamole has been attributed to increases level of endogenous adenosine which leads to renal vasoconstriction and a reduction in GFR as declared as in pathogenesis of CIN $[5,10]$. So, the aim of our study is to determine whether intravenous (iv) dipyridamole administration during MPS leads to impairment of renal functions in patients with reduced GFR by measuring SCr and Cys-C levels. To our knowledge there is no study in the literature has addressed the acute effect of intravenous dipyridamole on renal functions in patients with moderate degree renal failure.

\section{Material and method}

94 consecutive patients undergoing dipyridamole MPS enrolled to study between 2008 October and 2009 December. All patients were

Correspondence to: Muhsin Kalyoncuoglu, Haseki Training and Research Hospital,Department of Cardiology, Cardiologist, Instructor, Turkey, Tel: 00905337144547; Fax: 00902124627056; E-mail: mkalyoncuoglu80@hotmail.com

Key words: cDipyridamole, myocardial perfusion scintigraphy, glomerular filtration rate, cystatin $C$, renal impairment

Received: November 12, 2017; Accepted: December 19, 2017; Published: December 22, 2017 
informed detailly and signed written informed consent. A detailed medical history and information about having $\mathrm{CM}$ exposure within 10 days and receiving medication including angiotensine converting enzyme inbitor, angiotensine receptor bloker, NSAID, NAC, and teofilin were obtained and physical examination was performed in all patients. Exclusion criterions were patients with end stage renal disease and/or hemodialysis, abnormalities of thyroid function, steroid therapy, active infection, infection due to the human immune deficiency virus, systemic sepsis, systemic vascular or autoimmun disease and malignancy. $0.56 \mathrm{mg} / \mathrm{kg} /$ dipyridamole was administered intravenously to all patients. Two blood samples were taken from the antecubital vein directly for determination of serum blood urea nitrogen (BUN), $\mathrm{SCr}$, serum Cys-C levels and other biochemical parameters before, and at 4 and 48 hours after dipyridamole administration. One sample for biochemical parameters and SCr was immediately evaluated. The other blood sample for Cys-C was allowed to clot for 30 minutes before centrifugation and after centrifugation ( $3500 \mathrm{rpm}$ for $15 \mathrm{~min}$ ) were stored frozen at $-70^{\circ} \mathrm{C}$. Prior to assay, the frozen samples were brought to room temperature and mixed gently. Cys-C kit was measured by using particle-enhanced nephelometric immunoassay (Siemens Dade Behring, Marburg, Germany) with Dade Behring nephlometry analyzer BN II. Serum Cys-C level was accepted as normal with ranges of 0.53-0.95 mg/l.

GFR was calculated by using modification of diet in renal disease (MDRD) study equation and the chronic kidney disease-epidemiology collaboration (CKD-EPI) Cys-C equation modality [14,15]. Study population was divided into two groups separately regarding GFR obtained from the aferomentioned calculation modalities, as patients with GFR $>60 \mathrm{~mL} / \mathrm{dk} / 1.73 \mathrm{~m}^{2}$ (Group A) and GFR $\leq 60 \mathrm{ml} / \mathrm{dk} / 1.73 \mathrm{~m}^{2}$ (Group B). Dipyridamole induced nephropathy defined as $25 \%$ increase in SCr or Cys-C level or an absolute increase of $\geq 0.3 \mathrm{mg} / \mathrm{dL}$ in SCr from the baseline 48th hours after intravascular injection of dipyridamole. The incidence of nephropathy was compared between the two groups. The study was approved by the local ethics comittee.

\section{Statistical analysis}

Statistical analysis were performed using SPSS (Statistical Package for Social Sciences) for Windows version 15.0 (Chicago, Illinois, USA). Numerical variables were expressed as mean \pm SD and numbers and percentages were used for categorical variables. Comparison of rates for independent groups was tested by chi-square analysis. In situations where the requirements were not to be met, Monte Carlo simulation was applied. We also performed receiver-operating characteristic (ROC) curves to identify spesific threshold concentrations of SCr, Cys-C and GFR levels for maximized predictive value for the occurrence of nephropathy. Values of $\mathrm{p}<0.05$ were considered significant in all analyses.

\section{Result}

The mean age of the total study patients was $68.7 \pm 9.6$ (range from 35-87) years with 64 females and 30 males. Baseline (0 hour) mean SCr and Cys C levels of study population were 1,01 $\pm 0,29 \mathrm{mg} /$ $\mathrm{dl}$ (ranged from 0.60-2.10), and $1.20 \pm 0.45 \mathrm{mg} / \mathrm{l}$ (ranged from (0.662.93), respectively. Baseline GFR levels measured by aferomentioned calculation modalities were $64,7 \pm 16,8 \mathrm{~mL} / \mathrm{dk} / 1.73 \mathrm{~m}^{2}$ (MDRD-GFR), and $65,9 \pm 21,4 \mathrm{~mL} / \mathrm{dk} / 1.73 \mathrm{~m}^{2}$ (CKD-EPI Cys EQ-GFR). When we divided the study population according to calculation modalities, 61 (MDRD-GFR) and 52 (CKD-EPI Cys EQ-GFR) patients have GFR $\geq 60$ $\mathrm{mL} / \mathrm{dk} / 1.73 \mathrm{~m}^{2}$ (Group A). And the remains have $<60 \mathrm{ml} / \mathrm{dk} / 1.73 \mathrm{~m}^{2}$ (Group B). Table 1 represents the demographic and clinical data of two groups designated by both calculation modalities. We found that the patients in Group B in both calculation modalities were significantly elder and more hypertensive than group $\mathrm{A}$. The other demographic and clinical parameters did not show any significant difference between the groups. Table 2 represents the baseline levels and the changes in the renal function parameters at 4 th and 48 th hours after dipyridamole administration in both groups designated by calculation modalities. SCr levels did not exhibit any difference between the groups at 4 th and 48th hours in both calculation modalities. Besides that, only 4th hours Cys $\mathrm{C}$ level showed significantly increasing in patients with MDRDGFR $<60 \mathrm{~mL} / \mathrm{dk} / 1.73 \mathrm{~m}^{2}$ whereas 48 th hours Cys C levels did not ( $\mathrm{p}=$ $0.03, p=0.24$, respectively). Contrast to this finding we did not obtain any change in Cys $\mathrm{C}$ levels between the groups in the CKD-EPI Cys EQ calculation modality. We also demontrated that, parallel to the increase in serum Cys C levels, mean 4th hours GFR levels measured by CKD-EPI Cys EQ significantly reduced whereas 4th and 48th hours MDRD-GFR levels and 48th hours CKD-EPI Cys EQ-GFR did not in patients with MDRD-GFR $<60 \mathrm{~mL} / \mathrm{dk} / 1.73 \mathrm{~m}^{2}$ ( $\mathrm{p}=0.01, \mathrm{p}=1.0$, $\mathrm{p}=1.0, \mathrm{p}=0.29$, respectively). Besides that, when we used CKD-EPI Cys EQ modality at baseline in order to divide to study population, we did not observed any significant reductions in GFR levels measued by all calculation modalities in all groups. We also analyzed to detect the development risk of acute renal dysfunction between the gorups regarding increasing SCr and or Cys C levels at 4th and or 48th hours according to all calculation modalities, we did not observed significant difference between the groups (Table 3). Additionally, when we also performed ROC curve analysis, we did not obtain spesific threshold values of SCr, Cys C and baseline GFR levels according to all aferomentined calculation modalities for maximized predictive value for the development of nephropathy (Figure 1).

\section{Discussion}

In the present study we did not observe any significant change in Scr or Cys $\mathrm{C}$ levels measured 48 hours after dipiridamol injection during MPS in patients with GFR $<60 \mathrm{~mL} / \mathrm{dk} / 1.73 \mathrm{~m}^{2}$. We also observed that 4th hours Cys C level was significantly increased and mean 4th hours GFR levels measured by CKD-EPI Cys EQ was significantly reduced in patients with MDRD-GFR $<60 \mathrm{~mL} / \mathrm{dk} / 1.73 \mathrm{~m}^{2}$ after intravenous dipyridamole infusion. The clinical importance of this early rise of Cys $\mathrm{C}$ and fall of Cys EQ-GFR after dipiridamol injection remains unknown.

Table 1. Characteristics of demographic and clinical parameters of two groups designated by calculation modalities

\begin{tabular}{|l|c|c|c|c|c|c|}
\hline \multirow{2}{*}{$\begin{array}{l}\text { Demographic and clinical } \\
\text { parameters. }\end{array}$} & \multicolumn{3}{|c|}{ MDRD-GFR } & \multicolumn{3}{c|}{ CKD-EPI Cys EQ-GFR } \\
\cline { 2 - 7 } & $\begin{array}{c}\text { Group } \\
\text { Age (Median } \pm \text { SD) }\end{array}$ & $\begin{array}{c}\text { Group } \\
\text { B }\end{array}$ & p & $\begin{array}{c}\text { Group } \\
\text { A }\end{array}$ & $\begin{array}{c}\text { Group } \\
\text { B }\end{array}$ & p \\
\hline Female, n (\%) & $67 \pm 10$ & $71 \pm 7.6$ & 0.04 & $66 \pm 10$ & $69 \pm 8.1$ & 0.04 \\
\hline Medical history, n (\%) & $41(67)$ & $23(70)$ & 0,80 & $39(61)$ & $25(76)$ & 0.72 \\
\hline Current smoker, n (\%) & $6(10)$ & $4(12)$ & 0.73 & $6(10)$ & $4(12)$ & 0.73 \\
\hline Hypertension, n (\%) & $45(74)$ & $27(81)$ & 0.005 & $43(68)$ & $29(88)$ & 0.005 \\
\hline Dyslipidemia, n (\%) & $30(49)$ & $14(42)$ & 0.10 & $30(49)$ & $14(42)$ & 0.10 \\
\hline Diabetes Mellitus, n (\%) & $24(39)$ & $13(39)$ & 0.99 & $26(41)$ & $15(45)$ & 0.92 \\
\hline Heart failure history, n (\%) & $13(21)$ & $9(27)$ & 0.51 & $13(21)$ & $9(27)$ & 0.51 \\
\hline $\begin{array}{l}\text { CAD or equivilant history, } \\
\text { n (\%) }\end{array}$ & $16(26)$ & $14(42)$ & 0.11 & $15(23)$ & $15(45)$ & 0.10 \\
\hline $\begin{array}{l}\text { Cardiovascular medications, } \\
\text { n (\%) }\end{array}$ & & & & & & \\
\hline ACEI/ ARB, n (\%) & $46(75)$ & $26(79)$ & 0.71 & $44(73)$ & $28(80)$ & 0.69 \\
\hline Statin, n (\%) & $27(44)$ & $14(22)$ & 0.86 & $27(44)$ & $14(22)$ & 0.86 \\
\hline NAC, n (\%) & $0(0)$ & $0(0)$ & 0.00 & $0(0)$ & $0(0)$ & 0.00 \\
\hline NSAID, n (\%) & $13(21)$ & $2(6)$ & 0.54 & $13(21)$ & $2(6)$ & 0.54 \\
\hline
\end{tabular}


Table 2. Renal function parameters of two groups designated by calculation modalities

\begin{tabular}{|c|c|c|c|c|c|c|}
\hline \multirow[b]{2}{*}{ Renal function parameters. } & \multicolumn{3}{|c|}{ MDRD-GFR } & \multicolumn{3}{|c|}{ CKD-EPI Cys EQ-GFR } \\
\hline & Group A & Group B & $\mathbf{p}$ & Group A & Group B & $\mathbf{p}$ \\
\hline \multicolumn{7}{|l|}{ Serum creatinin, mean \pm SD, mg/dl } \\
\hline Baseline & $0.82 \pm 0.12$ & $1.26 \pm 0.29$ & & $0.81 \pm 0.10$ & $1.28 \pm 0.23$ & \\
\hline 4th hours & $0.91 \pm 0.17$ & $1.30 \pm 0.32$ & 1 & $0.93 \pm 0.15$ & $1.29 \pm 0.19$ & 0.09 \\
\hline 48th hours & $0.90 \pm 0.15$ & $1.24 \pm 0.34$ & 1 & $0.90 \pm 0.12$ & $1.24 \pm 0.30$ & 0.09 \\
\hline \multicolumn{7}{|l|}{ Serum Cystatine $\mathrm{C}, \mathrm{mean} \pm \mathrm{SD}, \mathrm{mg} / \mathrm{l}$} \\
\hline Baseline & $1.03 \pm 0.3$ & $1.50 \pm 0.5$ & & $1.03 \pm 0.4$ & $1.51 \pm 0.5$ & \\
\hline 4th hours & $1.04 \pm 0.3$ & $1.65 \pm 0.5$ & 0.03 & $1.06 \pm 0.3$ & $1.56 \pm 0.3$ & 0.69 \\
\hline 48th hours & $1.17 \pm 0.4$ & $1.52 \pm 0.3$ & 0.24 & $1.18 \pm 0.4$ & $1.60 \pm 0.2$ & 0.21 \\
\hline \multicolumn{7}{|c|}{ MDRD-GFR, mean $\pm \mathrm{SD}, \mathrm{mL} / \mathrm{dk} / 1.73 \mathrm{~m}^{2}$} \\
\hline Baseline & $78.2 \pm 12.5$ & $48.7 \pm 9.5$ & & $78 \pm 12.3$ & $51.8 \pm 9.2$ & \\
\hline 4th hours & $88 \pm 12.1$ & $47.9 \pm 10.7$ & 1 & $77 \pm 11.2$ & $51.3 \pm 12$ & 0.32 \\
\hline 48th hours & $77 \pm 13.1$ & $51.3 \pm 12.1$ & 1 & $79 \pm 9.6$ & $54.0 \pm 12.3$ & 0.2 \\
\hline \multicolumn{7}{|c|}{ CKD-EPI Cys EQ-GFR, mean $\pm \mathrm{SD}, \mathrm{mL} / \mathrm{dk} / 1.73 \mathrm{~m}^{2}$} \\
\hline Baseline & $75,0 \pm 19,1$ & $44,1 \pm 11,9$ & & $78,3 \pm 18,3$ & $43.0 \pm 9.2$ & \\
\hline 4th hours & $74,8 \pm 22,6$ & $38,0 \pm 12,1$ & 0.01 & $80,0 \pm 20,0$ & $42.8 \pm 13.6$ & 0.53 \\
\hline 48th hours & $65,3 \pm 21,6$ & $42,3 \pm 14,7$ & 0.29 & $67,8 \pm 21,7$ & $40.8 \pm 13.9$ & 0.19 \\
\hline
\end{tabular}

Table 3. Comparing to gorups for development of nephropathy risk regarding to inreasing creatinin and or cystatin C levels at 4th and or 48th hour

\begin{tabular}{|c|c|c|c|c|c|c|}
\hline \multirow[b]{2}{*}{ Renal function parameters. } & \multicolumn{2}{|c|}{ MDRD-GFR } & \multirow[b]{2}{*}{$\mathrm{p}$} & \multicolumn{3}{|c|}{ CKD-EPI Cys EQ-GFR } \\
\hline & $\begin{array}{c}\text { Group A } \\
\mathrm{n}(\%)\end{array}$ & $\begin{array}{c}\text { Group B } \\
\text { n }(\%)\end{array}$ & & $\begin{array}{c}\text { Group A } \\
\mathrm{n}(\%)\end{array}$ & $\begin{array}{c}\text { Group B } \\
\mathrm{n}(\%)\end{array}$ & $\mathrm{p}$ \\
\hline \multicolumn{7}{|c|}{ Increasing in the creatinin and or cystatin $-\mathrm{C}$ level $\mathrm{n}(\%)$ at $4 \mathrm{~h}$ and/or $48 \mathrm{~h}$} \\
\hline Yes & $25(41)$ & $17(51)$ & 0.33 & $25(48)$ & $17(40)$ & 0.46 \\
\hline No & $36(59)$ & $16(49)$ & & $27(52)$ & $25(60)$ & \\
\hline
\end{tabular}
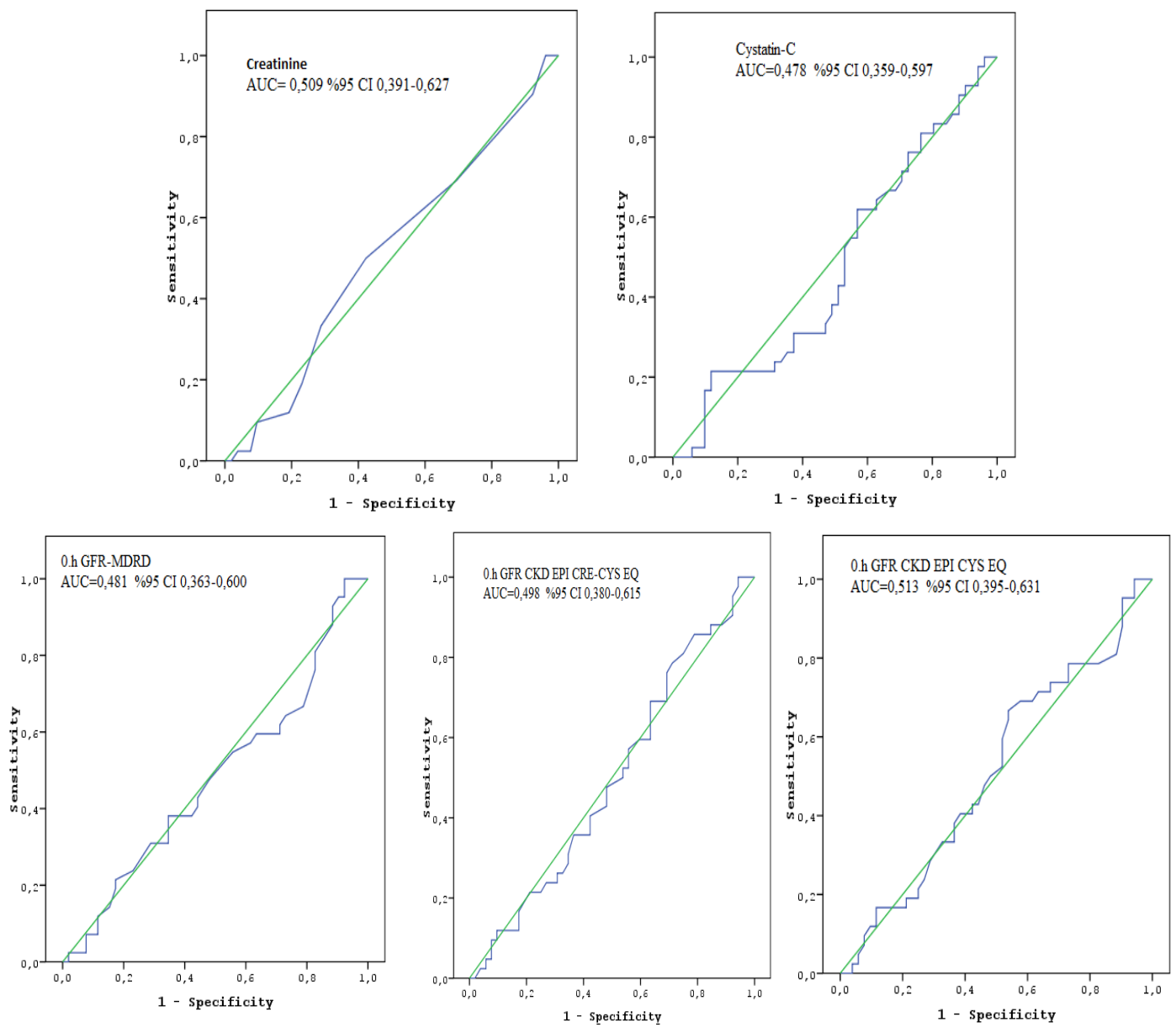

Figure 1. ROC curves did not show spesific threshold values of creatinine, Cys-C and GFR levels for maximized predictive value for the occurrence of nephropathy. 
In routine clinical practice, $\mathrm{SCr}$ is mostly used diagnostic marker for the estimation of GFR as a marker for diagnosing and staging of acute kidney injury. Unfortunately, SCr is influenced by several nonrenal factors such as muscle mass, age, race, gender, and medications. So it has also insensitivity for small to moderate decreases in GFR in creatinine blind GFR area $\left(40-70 \mathrm{ml} / \mathrm{min} / 1.73 \mathrm{~m}^{2}\right)$ gives false sense of security and late detection of kidney damage [13,19]. Contrast to Scr, although there are contradictory results, previous studies mostly showed that Cys $\mathrm{C}$ was more sensitive marker to detect both chronic and acute changes in renal function than Scr and rises earlier in acute kidney injury following various conditions such as after adult or pediatric cardiac surgery and CM exposure during coronary angiography [11,14,19-23]. The underlying mechanisms of contrast induced nephropathy (CIN) such as increased vasoconstrictive forces, direct toxic effect, increased intratubular pressure, are complex and not fully understood $[9,10]$. It has been reported that, an elevated endogenous adenosine has an important role in development pathogenesis of CIN and dipyridamole as an adenosine uptake inhibitor may be contributor for the fall in GFR after CM exposure [10]. In the present study, we evaluated the acute effect of iv dipyridamole administration on renal function with regard to contributor effect of dipyridimole via potentiating the intrarenal effects of adenosine in pathogenesis of CIN. We did not observe acute renal impairment between the groups regarding absolute $\geq 0.3 \mathrm{mg} /$ $\mathrm{dL}$ or $25 \%$ increasing in SCr level and/or $25 \%$ increasing in serum Cys $\mathrm{C}$ levels and/or decreasing GFR levels at 4 th and or 48th hours by using MDRD and CKD-EPI Cys EQ calculation modalities whereas we observed significant increasing Cys $\mathrm{Clevel}$ at 4 th hours. We also did not any cuttoff levels of Cys C and/or Scr for predicting the development of acute renal impairment. In a study Briguori et al. demonstrated that, $10 \%$ increase in Cys $\mathrm{C}$ level as the best cuttoff level at 24 hours after CM exposure was predictive for early diagnosis and prognosis of contrast induced acute kidney injury defined as a SCr increase $0.3 \mathrm{mg} /$ $\mathrm{dL}$ at 48 hours after contrast media exposure [19]. In another study, Rickli et al. compared Cys C and SCr to examine their kinetics at $5 \mathrm{~h}$, $24 \mathrm{~h}$ and $48 \mathrm{~h}$ after administration of $\mathrm{CM}$ in patients with normal to subnormal GFR scheduled for coronary angiography. At 5 hours after angiography, there was no significant change compared to baseline in either SCr nor Cys C whereas the increase of Cys C achieved a maximum at $24 \mathrm{~h}$ after the application of the CM. They also found that Cys $\mathrm{C}$ decreased to the level before angiography within $48 \mathrm{~h}$ after administration of CM [18]. In another study, Kato et al. analyzed the diagnostic performance of Cys $\mathrm{C}$ and $\mathrm{SCr}$ in consecutive 87 patients with moderate renal disease (defined as GFR $30-59 \mathrm{ml} / \mathrm{min} / 1.73 \mathrm{~m}^{2}$ ). In this study, Cys $\mathrm{C}$ and SCr levels were measured immediately before, and 1,2, and 3 days after CM exposure. They revealed that Cys C was useful for predicting the occurrence of CIN at a cut-off level of $>1.2 \mathrm{mg} / \mathrm{L}$ of Cys C before indexed catheterization [24]. But they did not address the performance of early diagnosis of CIN. Contrast to aferomentioned studies, in an another study, compared head to head the serum Cys $\mathrm{C}$ and SCr, Ribichini et al. found that absolute changes in SCr were more accurate than Cys C for predicting CIN at an early stage (12 h after the renal insult) and lacking additional diagnostic value of Cys $\mathrm{C}$ over the determination of Scr in the setting of CIN. As a summary, studies aimed to investigate the prognostic value of Cys $\mathrm{C}$ on early diagnosis of CIN are inconsistent. Besides that, some previous studies have found that many factors other than renal function may influence Cys $C$ levels and supposed the possibility that Cys $C$ values may be influenced by gender, increasing age, smoking, weight and height and higher C-reactive protein levels by increasing production and or catabolism of Cys C [9,25-27]. Additionally some studies have reported that the prevalence of an elevated serum Cys $\mathrm{C}$ was associated with the presence of classical cardiovascular risk factors such as age, diabetes and hypertension [27-29]. So, In the current study, we think that, increasing Cys C levels and calculated reduced GFR levels by using Cys-C based calculation modality at 4 th hour, may be associated older age and more hypertension incidence in group $\mathrm{B}$ rather than renal factor.

Increasing the concentration of adenosine in renal tissue with renal injury caused by ischemia or nephrotoxic agents supposes that adenosine is an important intrarenal factor in the pathogenesis of acute renal impairment [5]. It has also reported that inhibition of adenosine reuptake by dipyridamole induced the reduction of GFR and significantly increases the severity of renal impairment in response to $\mathrm{CM}$ and causes to a $70 \%$ decreasing in total reperfusion $[5,28,29]$. In a study, Latham et al. observed that dipyridamole infusion reduced renal blood flow and GFR measured by time-activity curves of left and right kidney by using Tehnetium-99-DTPA in healthy five patients [8]. In contrary Puri et al. observed that dipyridamole showed renoprotective effect against ischemia reperfusion induced acute kidney injury via adenosinergic $\mathrm{A} 1$ and $\mathrm{A} 2 \mathrm{~A}$ receptors in an animal study [30]. Additionaly experimental studies observed that adenosine, as an endogenous signaling molecule, plays a critical role in attenuating renal inflammation and renoprotection from acute ischemic renal failure [31-34]. There are conflicting data about effects of dipyridamole on renal function but not proteinuria, as it was reported that dipyridamole was shown to decrease proteinuria and or risk for rapid renal and development of end stage renal disease especially in early chronic kidney disease patients with diabetic nephropathy and various primary glomerulonephropathies such as IgA nephropathy, and membranoproliferative glomerulonephritis [30,35-37]. Although the underlying mechanism is exactly unknown, several mechanisms supposed to renoprotective effect of dipyridamole such as inhibition of platelet activation and aggregation by increasing adenosine level, vasodilation via enhancing the nitric oxide pathway, acting as a antioxidant and inhibiting cellular proliferation of mesengial cells and renal fibroblasts and extracellular matrix accumulation [35].

Consequently, there are little and conflict data about effect of dipyridamole on the renal renal function especially in patients with impaired renal function. Although dipyridamole effects via increasing extracellular adenosine concentration by the reducing the uptake of adenosine, in the light of the literature, we think that dipyridamol may not effect renal function by itself without facilitating factors for development kidney injury such as hypotension, ischemia, nehrotoxic drugs, hypovolemia, administration contrast media leading to medullary hypoxia, tubular toxicity and oxidative damage as seen in the pathophysiology of contrast induced nephropathy [5,9,35-37].

Our study has some limitations. First, because of outpatient study population and difficulties to obtain blood samples, we did not analyzed serum Cys C levels at $24 \mathrm{~h}$ after index procedure contrast to previous studies suggested the maximum increase of Cys $\mathrm{C}$ levels within $24 \mathrm{~h}$ after CM exposure $[18,19,24]$. So, we can not exclude the possibility that increase in serum Cys $\mathrm{C}$ level may occur. Second, in the current study, as the development of nephropathy has not been observed, we did not analyzed significance of absolute and relative increases in Cys $\mathrm{C}$ levels ( $\Delta$ Cys $\mathrm{C}$ ). Third, we use only Cys $\mathrm{C}$ as a sensitive marker of early renal impairment and reduction in GFR rather than the other biomarkers such as kidney injury molecule-1, neutrophilin gelatinaseassociated lipocalin suggested to rise much more quickly in response to acute kidney injury. 
So, in patients with moderate degree renal failure and suspected coronary artery disease whom cannot perform or tolerate exercise, dipyridamole myocardial perfusion scintigraphy can be used safely for clinical diagnosis and/or risk straficiation. Besides that, drinking plenty of water and avoidance of nephrotoxic agents may be a reasonable approach during first 24 th hours after index test.

\section{Conclusion}

Although we observed an increasing of serum cystatin $\mathrm{C}$ level at 4th hour after dipyridamole administration, we did not find significantly acute kidney impairment measured by GFR according to aferomentioned calculation modalities. So, in patients with moderate degree renal failure and suspected coronary artery disese whom cannot perform or tolerate exercise dipridamol myocardial perfusion scintigraphy can be used safely for clinical diagnosis and/or risk straficiation.

\section{References}

1. Lee J, Chae SC, Lee K, Heo J, Iskandrian AS (1994) Biokinetics of thallium-201 in normal subjects: Comparation between adenosine, dipyridamole, dobutamine and exercise. J Nucl Med 35: 535-541.

2. Belardinelli R, Belardinelli L, Shryock JC (2001) Effects of dipyridamole on coronary collateralization and myocardial perfusion in patients with ischaemic cardiomyopathy. Eur H J 22: 1205-1213.

3. Seideman P, Sollevi A, Fredholm BB (1987) Additive renal effects of indomethacin and dipyridamole in man. Br J Clin Pharmacol 23: 323-330. [Crossref]

4. Degenring FH, Curnish RR, Rubio R, Berne RM (1976) Effect of dipyridamole on myocardial adenosine metabolism and coronary flow in hypoxia and reactive hyperemia in the isolated perfused guinea pig heart. $J$ Mol Cell Cardiol 8:877-888. [Crossref]

5. Rohani A (2010) Effectiveness of aminophylline prophylaxis of renal impairment after coronary angiography in patients with chronic renal insuffiency. Indian J Nephrol 20: 80-83. [Crossref]

6. Persson PB, Hansell P, Liss P (2005) Pathophysiology of contrast medium-induced nephropathy. Kidney Int 68: 14-22. [Crossref]

7. Rudnick MR, Kesselheim A, Goldfarb S (2006) Contrast-induced nephropathy: How it develops, how to prevent it. Cleveland Clinic Journal of Medicine 73: 75-87. [Crossref]

8. Latham TB, Prato FS, Wisenberg G, Reese L (1992) Effects of dipyridamole infusion on human renal function observed using technetium-99m-DTPA. J Nucl Med 33: 355358. [Crossref]

9. Gleeson TG, Bulugahapitiya S (2004) Contrast-induced nephropathy. AJR Am J Roentgenol 183: 1673-1689. [Crossref]

10. Katholi RE (2006) Contrast-induced Nephropathy-Update and Practical Clinical Applications. US Cardiology 3: 73-80.

11. Kim BJ, Sung KC, Kim BS, Kang JH, Lee KB, et al. (2010) Effect of N Acetylcysteine on cystatin C-Based renaL function after Elective coronary angiography (ENABLE Study): A prospective, randomized trial. Int J Cardiol 138: 239-245. [Crossref]

12. Hoek FJ, Kemperman Frits AW, Krediet RT (2003) A comparison between cystatin C, plasma creatinine and the Cockcroft and Gault formula for the estimation of glomerular filtration rate. Nephrol Dial Transplant 18: 2024-2031. [Crossref]

13. Murty MSN, Sharma UK, Pandey VB, Kankare SB (2013) Serum cystatin C as a marker of renal function in detection of early acute kidney injury. Indian J Nephrol 23: 180-183. [Crossref]

14. Herget-Rosental S, Bökenkamp A,Hofmann W (2007) How to estimate GFR-serum creatinine, serum cystatin C or equations? Clin Biochem 40: 153-161. [Crossref]

15. Madero M, Sarnak MJ, Stevens LA (2006) Serum cystatin C as a marker of glomerular filtration rate. Curr Opin Nephrol Hypertens 15: 610-616. [Crossref]

16. Ribichini F, Gambaro G, Graziani MS, Pighi M, Pesarini G, et al. (2012) Comparison of Serum Creatinine and Cystatin C for Early Diagnosis of Contrast-Induced Nephropathy after Coronary Angiography and Interventions. Clinical Chemistry 58: 2458-464. [Crossref]

17. Dharnidharka V, Kwon C, Stevens G (2002) Serum cystatin C is superior to serum creatinine as a marker of kidney function: a meta-analysis. Am J Kidney Dis 40:221226. [Crossref]
18. Rickli H, Benou K, Ammann P, Fehr T, Brunner-La Rocca HP, et al. (2004) Time course of serial cystatin $\mathrm{C}$ levels in comparison with serum creatinine after application of radiocontrast media. Clin Nephrol 61: 98-102. [Crossref]

19. Briguori C, Visconti G, Rivera NV, Focaccio A, Golia B, et al. (2010) Cystatin C and contrast-induced acute kidney injury. Circulation 121: 2117-2122. [Crossref]

20. Zand F, Sabetian G, Abbasi G, Rezaianzadeh A, Salehi A, et al. (2015) Early Acute Kidney Injury based on Serum Creatinine or Cystatin C in Intensive Care Unit after Major Trauma. Iran J Med Sci 40: 485-492. [Crossref]

21. Bongiovanni C, Magrini L, Salerno G, Gori CS, Cardelli P, et al. (2015) Serum Cystatin $\mathrm{C}$ for the Diagnosis of Acute Kidney Injury in Patients Admitted in the Emergency Department. Disease Markers 1-7.

22. Zahran A, El-Husseini, Shoker A (2007) Can Cystatin C Replace Creatinine to Estimate Glomerular Filtration Rate? A Literature Review. Am J Nephrol 27:197-205. [Crossref]

23. Knight EL, Verhave JC, Spiegelman D, Hillege HL, de Zeeuw D, et al. (2004) Factors influencing serum cystatin $\mathrm{C}$ levels other than renal function and impact on renal function measurement. Kidney Int 65: 1416-1421. [Crossref]

24. Kato K, Sato N, Yamamoto T, Iwasaki YK, Tanaka K, et al. (2008) Valuable markers for contrastinduced nephropathy in patients undergoing cardiac catheterization. Circ $J$ 72: 1499-1505. [Crossref]

25. Yashiro M, Kamata T, Segawa H, Kadoya Y, Murakami T, et al. (2009) Comparisons of cystatin $\mathrm{C}$ with creatinine for evaluation of renal function in chronic kidney disease. Clin Exp Nephrol 13: 598-604. [Crossref]

26. Anoop S, Srinivas T (2011) Relationship between serum cystatin C and hypertension among US adults without clinically recognized chronic kidney disease. $J$ Am Soc Hypertens 5: 378-384. [Crossref]

27. Cepeda J, Tranche-Iparraguirre S, Marín-Iranzo R, Fernández-Rodríguez E, RiesgoGarcía A, et al. (2010) Cystatin C and cardiovascular risk in the general population. Rev Esp Cardiol 63: 415-422. [Crossref]

28. Huber W, Schipek C, Ilgmann K, Page M, Hennig M, et al. (2003) Effectiveness of Theophylline Prophylaxis of Renal Impairment After Coronary Angiography in Patients With Chronic Renal Insufficiency. Am J Cardiol 91: 1157-1162. [Crossref]

29. Vallon V, Mühlbauer B, Osswald H (2006) Adenosine and kidney function. Physiol $\operatorname{Rev}$ 86: 901-940. [Crossref]

30. Puri N, Mohey V, Singh M, Kaur T, Pathak D, et al. (2016) Dipyridamole attenuates ischemia reperfusion induced acute kidney injury through adenosinergic A1 and A2A receptor agonism in rats. Naunyn Schmiedebergs Arch Pharmacol 389: 1-8. [Crossref]

31. Bauerle JD, Grenz A, Kim JH, Lee HT, Eltzschig HK (2011) Adenosine generation and signaling during acute kidney injury. J Am Soc Nephrol 22: 14-20. [Crossref]

32. Kim M, Chen SW, Park SW, Kim M, D’Agati VD, et al. (2009) Kidney-specific reconstitution of the $\mathrm{A} 1$ adenosine receptor in $\mathrm{A} 1$ adenosine receptor knockout mice reduces renal ischemia-reperfusion injury. Kidney Int 75: 809-823. [Crossref]

33. Kinsey GR, Sharma R, Huang L, Li L, Vergis AL, et al. (2009) Regulatory T cells suppress innate immunity in kidney ischemia-reperfusion injury. J Am Soc Nephrol 20: 1744-1753. [Crossref]

34. Eltzschig HK (2009) Adenosine: an old drug newly discovered. Anesthesiology 111 904-915. [Crossref]

35. Hung CC, Yang ML, Lin MY, Lin HY, Lim LM, et al. (2014) Dipyridamole treatment is associated with improved renal outcome and patient survival in advanced chronic kidney disease. Kaohsiung J Med Sci 30: 599-607. [Crossref]

36. Taji Y, Kuwahara T, Shikata S, Morimoto T (2006) Meta-analysis of antiplatelet therapy for IgA nephropathy. Clin Exp Nephrol 10: 268-273. [Crossref]

37. Zäuner I, Böhler J, Braun N, Grupp C, Heering P, et al. (1994) Effect of aspirin and dipyridamole on proteinuria in idiopathic membranoproliferative glomerulonephritis: a multicentre prospective clinical trial. Collaborative Glomerulonephritis Therapy Study Group (CGTS). Nephrol Dial Transplant 9: 619-622. [Crossref]

Copyright: (C2017 Kalyoncuoglu M. This is an open-access article distributed under the terms of the Creative Commons Attribution License, which permits unrestricted use, distribution, and reproduction in any medium, provided the original author and source are credited. 